\title{
Packhorse grazing behavior and immediate impact on a timberline meadow
}

\author{
K.M. OLSON-RUTZ, C.B. MARLOW, K. HANSEN, L.C. GAGNON, AND R.J. ROSSI
}

\begin{abstract}
Authors are former research associate, Animal and Range Sciences Department, Montana State University, Bozeman, Mont., 59717; associate professor, Animal and Range Sciences Department, Montana State University, Bozeman, Mont., 59717; associate professor, Earth Sciences Department, Montana State University, Bozeman, Mont., 59717; associate professor, Animal and Range Sciences Department, Montana State University, Bozeman, Mont., 59717; and assistant professor, Math and Computer Sciences Department, Montana Tech, Butte, Mont., 59701.
\end{abstract}

\begin{abstract}
Recreational packhorse grazing is one of many uses of high elevation wildland meadows. We quantified the behavior of horses grazing on an upper timberline meadow in southwestern Montana and the immediate impact on the plant community. Horses were picketed on 15-m diameter circles for different durations (0, 4, 8, 18 hours), months (July, August, September), and frequencies (1 month only, all 3 months) over 3 summers. We recorded the amount of time horses spent grazing or resting, horse movement while grazing, plant height, and grazed plant frequency before and after grazing. Grazing was the dominant activity throughout the trial. After an initial 3-4 hour feeding bout, horses continued to graze intermittently. When not grazing, horses rested more than walked. Horses grazed a higher percent of grasses at first ( 4 hour picket duration) but the percent of forbs grazed increased with increased time on picket. After 18 hours of use, or after repeated use on the same picket circle through the summer, more than $50 \%$ of the grasses and $20 \%$ of the forbs had been grazed and tallest plant material was less than $12 \mathrm{~cm}$ tall. Recreational packhorse management should include previous training (picket grazing experience), limiting time on specific circles to 8 hours or less, and using picket circles only once each season.
\end{abstract}

Key Words: diet selection, forage removal, horse, mountain meadow

Range management practices have been developed largely to enhance or maintain a sustained level of productivity from rangelands. Thus, the change in plant community composition induced by grazing is usually balanced with economic concerns. Such management philosophy is generally accepted for use on most rangeland, but it may be unacceptable for Wilderness Areas (Cole 1989, McClaran and Cole 1993). Changes in vegetation composition would be unacceptable regardless of the potential economic output because the loss or diminution of the "naturalness" of a wilderness site reduces its value as wilderness (Stankey and

\footnotetext{
This project as funded by the Intermountain Research Station, Forest Service, USDA, and the Mfontana Agricultural Experiment Station. We appreciate the advice from David Cole, (USFS, Missoula, Mont.) and the help of all the field workers. We thank John Lacey, Matt Lavin, Jim Pfister, and 2 Joumal of Range Management reviewers for their comments.

Manuscript accepted 20 Dec. 1995.
}

Schreyer 1987). Most grazing literature addresses plant or animal production issues which may not be pertinent to wilderness management problems (Cole 1987, McClaran and Cole 1993).

In July 1988 we began a field study to quantify horse (Equus caballus) grazing impacts on an upper timberline meadow in a federally designated wilderness. We simulated recreational packhorse management by grazing horses on picket circles and tying them to a high-line when they were not grazing or being ridden. We quantified horse behavior while on pickets and recorded proportion of grasses and forbs grazed and plant heights immediately before and after horses grazed. Comparisons of grazing induced changes were made with similar measurements taken on nearby ungrazed areas and may be useful in assessing horse grazing impacts and developing wilderness management guidelines.

\section{Methods}

\section{Study Site}

Grazing experiments were conducted in a $40-50$ ha meadow/timber complex in the headwaters of Bacon Rind Creek. This stream lies within the Lee Metcalf Wilderness of southwestern Montana at approximately $111^{\circ} 10^{\prime}$ longitude and $44^{\circ} 58^{\prime}$ latitude. The study site is characterized as an upper timberline meadow $(2,700 \mathrm{~m}$ elevation) with fine, textured soils of the Cryoboroll or Cryochrept group (Montagne et al. 1982). The plant community is classified as a Festuca idahoensis/Elymus trachycaulus habitat type (Mueggler and Stewart 1980). While large numbers of elk (Cervus elaphus elaphus) use the area during summer and early fall, records of the Hebgen Ranger District, Gallatin National Forest, indicate that the area was never part of a livestock grazing allotment. In addition, there is little recreational horse use in the area because of limited hunting and fishing opportunities. Thus, we considered the plant community at our study site undisturbed by human or domestic animal activity.

\section{Grazing Treatments}

Horses were constrained to a given area for grazing by a $15 \mathrm{~m}$ picket rope. By attaching 1 end of the rope to a horse's front foot and tying the other end to a metal stake in the ground, each horse grazed a circular area of $175 \mathrm{~m}^{2}$. The grazing treatments were a) the duration a circle was grazed ( $0=$ ungrazed control, 4,8 , or 18 hours) and b) the month the circle was grazed (July, August, or 
September). In 1988, there were 4 replicate circles per month by duration combination for a total of 48 circles which were randomly interspersed on a 3 ha portion of the meadow.

In 1989, we applied the same treatments to a different 3 ha portion of the same meadow. We included circles which were grazed repeatedly during the summer (frequency) to assess the impact of repeated visits to a given site. These circles were grazed for 4 or 8 hours in July, again in August, and for a third time in September (hereafter referred to as JAS circles). All 56 circles used in 1989 were regrazed in 1990 with the same month, duration, and frequency treatment.

We used mature Quarter Horses trained to grazing on pickets while on pack trips in previous summers. The 4-hour circles were grazed a continuous 4 hours. The 8 -hour circles were grazed twice each for 4 hours. Horses grazing these circles were placed on the pickets in mornings and again at evening. The 18-hour circles were grazed for 9 continuous hours on each of 2 consecutive days, beginning in the morning. The horses watered after their grazing time, except those grazing for 9 hours which were also watered mid-way through their 9 hour grazing time. Horses were maintained on a high-line when not on a treatment picket or being ridden. Individual horses were assigned to the same duration of grazing in all months. There were 4 to 12 horses grazing at any given time and all grazing treatments were applied over a 3 day period.

\section{Horse Behavior and Plant Measures}

Picketed horses were observed in 1988 and 1989. Horses were not observed while grazing the repeatedly grazed (JAS) circles. Beginning 1/2-hour after picketing, each horse was watched for 15 continuous seconds every 5 minutes for the next $1 / 2$-hour. The 1/2-hour observation periods were alternated with $1 / 2$-hour of no observations. During the 15 second observation we noted whether the horse grazed, traveled, or rested, and the number of grazing stations used. Grazing stations were defined as areas grazed that were separated by at least 2 steps taken by the horse. This observation method was a combination of a focal animal and instantaneous sampling method (Altmann 1964). The 15 second focal period was necessary to get information on grazing stations, but short enough to enable observing all horses within a few minutes, therefore similar to an instantaneous sampling method. Jacobsen and Wiggins (1982) found instantaneous sampling to have the highest correspondence between estimate and actual time-inactivity if the intervals between sampling were less than or equal to 5 minutes, which ours were. However, because of the $15 \mathrm{sec}-$ ond observation period, more than 1 activity could occur and be recorded at 1 observation time.

To determine whether month or duration of grazing influenced horse behavior on the picket circles, we calculated the average of the proportion of observations in which grazing, resting, or traveling occurred during each $1 / 2$-hour observation period, per horse. These data were analyzed as an AOV (SAS 1988) with month and duration of grazing as main effects and replicate (horse) within grazing duration as error term for duration.

To determine whether horses rest quietly or walk when finished with grazing, we used a step-wise regression to test the correlation between hourly proportion of observations in which horses were grazing and hourly proportion of observations where horses were resting. The model was,

$$
\text { graze }=\text { hour }+ \text { hour }{ }^{2}+\text { month }+ \text { stint }+ \text { rest }
$$

where graze and rest are hourly proportions of the respective behaviors, hour is the actual hour on the picket circle (1-9), month is the month of grazing, and stint is the time the horse was on the picket (1 for all 4-hour horses, 1 or 2 for the 8 and 18-hour horses depending on whether the horse was on the circle for the first or second half of the total duration of grazing).

We tested for a linear and quadratic relationship between hourly grazing observations and time (h) on picket circle (GLM, SAS 1988) by month of grazing. Number of grazing stations was analyzed in the same manner.

Plant measurements were recorded before and after horses grazed. Measurements were made in $2 \times 5 \mathrm{~cm}$ frames at $0.30 \mathrm{~m}$ intervals along $\mathrm{N}$ to $\mathrm{S}$ and $\mathrm{E}$ to $\mathrm{W}$ diameter transects. Only the outer $4 \mathrm{~m}$ of the $\mathrm{E}$ and $\mathrm{W}$ transects were measured to avoid over sampling circle interiors. In 1988 we noted the height class $(0$, no plant present; $1,0-2 \mathrm{~cm} ; 2,2-4 \mathrm{~cm} ; 3,4-12 \mathrm{~cm} ; 4,12-24 \mathrm{~cm} ; 5$, $>24 \mathrm{~cm}$ ) of the tallest plant material. In 1989 and 1990 plant height classes were recorded for the tallest of each plant type (grass and forb) and we noted whether any grasses or forbs had been grazed within the $2 \times 5 \mathrm{~cm}$ frame.

To describe the immediate impact of horse grazing on plant heights, we analyzed both the post-grazing and the change in (post- minus pregrazing) the proportion of plants in each height class with an AOV. The model had grazing duration, grazing month, and vegetation type (grass or forb) as main effects with all 2 - and 3-way interactions. There were many significant interactions, which are hard to interpret. Therefore, we present the mean monthly means and standard errors of the proportion of plants in each height class after horse grazing.

The percentage of plants grazed before horses grazed the circles was attributed to elk grazing. To determine how much the horses grazed, these pregrazing values should be subtracted from the percentage of plants grazed after the horses were removed. However, to contrast the impact of a single grazing with 3 grazings per summer we had to analyze the percentage of plants grazed after the horses finished grazing, because on the repeatedly grazed circles (JAS), once the horses had grazed the circles, we could not, in subsequent pregrazing measurements, distinguish between elk and horse use. On those circles grazed only once during the summer, month of grazing did not influence plants grazed, therefore we present the means of monthly means and monthly standard errors. Values presented for the JAS-4 and JAS-8 circles represent percentage of plants grazed after the September grazing treatment.

We used stepwise regression (SAS 1988) to analyze the proportion of grasses and forbs grazed by horses as a function of actual hours horses grazed, proportion of plants taller than $12 \mathrm{~cm}$ before grazing, and proportion of plants taller than $24 \mathrm{~cm}$ before grazing. We expect fewer plants to be grazed in tall than short vegetation. Also, a tight relationship between plants grazed and time spent on pickets or hours grazed would indicate grazed plant frequency could be used by managers to estimate how many additional hours horses could graze an area to reach a given level of plant use. These analyses were done with the 1989 data, the only year we collected both proportion of plants grazed and horse behavior data.

With all data, years were analyzed separately. To meet normality assumptions, proportions and percents were arcsine squareroot transformed for analyses, but arithmetic means and standard errors are presented. We chose $\alpha=0.10$ for all tests. 


\section{Results}

\section{Horse Behavior}

In 1988 horses grazed during $70 \% \pm 5.6( \pm$ average monthly SE among horses) of the observations, rested during $34.5 \% \pm 6.5$, and walked during $3.9 \% \pm 1.5$. These do not add to 100 because more than 1 behavior could be noted during a 15-second observation period. The month or duration spent on picket circles did not statistically influence how horses spent their time.

In 1989, horses spent more time grazing, and less time resting or walking than in 1988. In July and August 1989, horses spent more time grazing $(88.1 \% \pm 3.9)$ and less time resting $(10.7 \% \pm 3.9)$ than in September $1989(78.6 \% \pm 3.5$ and $20.3 \% \pm 3.5$ respectively). Time spent walking was the same all 3 months $(1.5 \% \pm 0.8)$ of 1989.

There was a moderate negative correlation between grazing and resting in 1988 (Partial correlation coefficient $=0.56$, slope estimate $=-0.69$ ). The correlation was lower in July than in August and September (data not shown). The correlation was stronger in 1989 (Partial correlation coefficient $=0.97$, slope estimate $=$ $-1.05)$ than in 1988 and consistent across months. The correlation did not change over the course of time on the picket line.

Time spent grazing and grazing stations used over time on the picket circle did not fit a linear or quadratic pattern. The horses tended to graze avidly during the first 3 to 4 hours and intermittently during the rest of the time on the picket circle (Fig. 1). Number of grazing stations was consistent between years (data not shown), among months, and throughout the duration on the picket circle (Fig. 1).

\section{Plant Impact}

Plant height class distributions changed with grazing (Fig. 2). In 1988 more plants were measured in short $(<4 \mathrm{~cm})$ than tall $(>4$ $\mathrm{cm}$ ) height classes as grazing duration increased (Fig. 2a). Although a similar relationship was found in 1989 (Fig. 2b), more hours of grazing were required in 1989 to produce a similar post-grazing plant height distribution as in 1988 . In 1989, grass heights appeared to be reduced more than forb heights. The impact of grazing was similar in 1990 (Fig. 2c). Grass heights were reduced as grazing duration increased, however, forb heights changed little even after 18 hours of grazing. In 1990 there were more tall grasses and forbs than in 1989 (Fig. 2b,c 0hour).

The cumulative impact of repeated grazing through the summer (JAS-4, JAS-8) on plant height class distribution was severe (Fig. $2 \mathrm{~b}, \mathrm{c})$. By the end of the summer most plants on the repeatedly grazed 8-hour circles (JAS-8) were shorter than $12 \mathrm{~cm}$ (height classes 4 and 5), which is lower than on the circles grazed once for 18 hours. After repeated grazing, grasses and forbs in the 8hour circles appeared to have the same height class distribution. In contrast, after repeated 4-hour grazing most forbs were less than $2 \mathrm{~cm}$ tall while most grasses were in the $4-12 \mathrm{~cm}$ height class (class 3 ). This can be misleading, since the controls (0-hour) also had a greater proportion of forbs than grasses in small height classes and we measured the tallest remaining plant material rather than average plant height.

Percent of grasses grazed increased with duration of grazing (Table 1). Forb use was the same after 4 and 8 hours of grazing, but increased with 18 hours of grazing. This indicates that horses prefer not to graze forbs until they are forced to remain on an area for longer than 8 hours. The cumulative impact of repeatedly
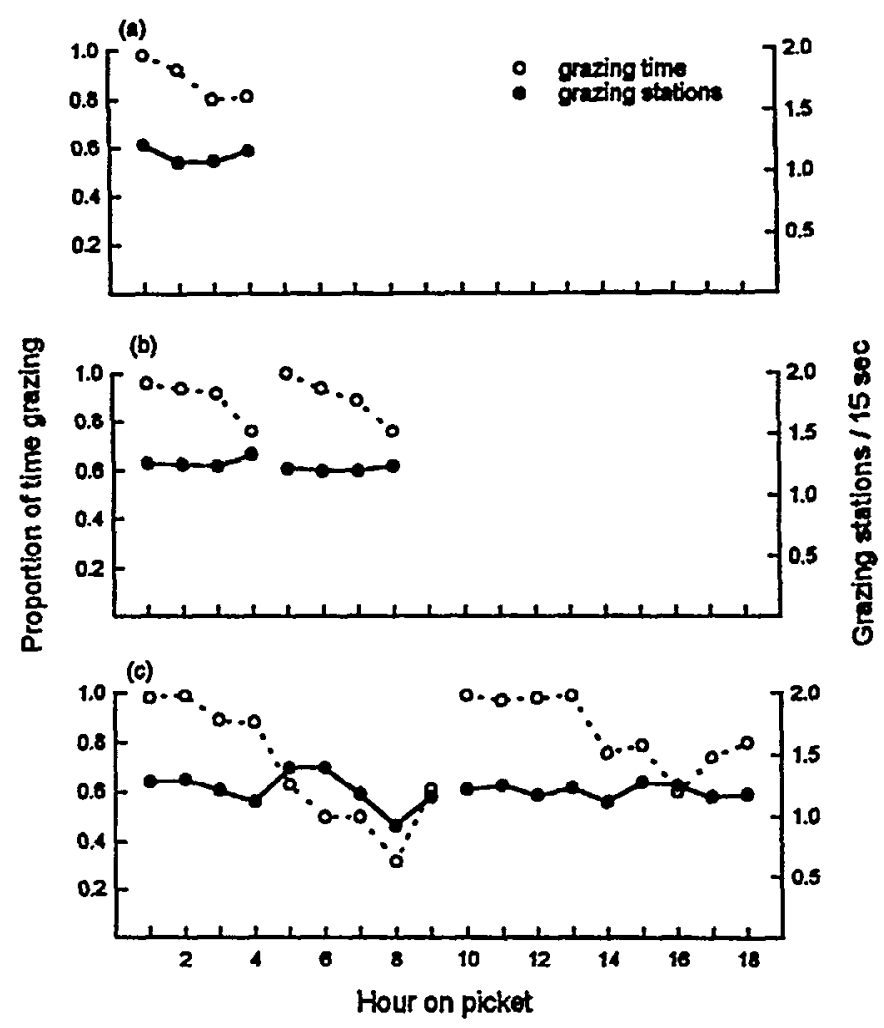

Fig. 1. Hourly proportion of time horses spent grazing and the mean number of grazing stations horses used during 15 second observation periods. Horses were on pickets for; a) 4, b) 8 , and c) 18 hours. Means are of $\mathbf{4}$ horses, grazing new picket circles in each of 3 months over 2 summers.

grazing 4 and 8 hours through the summer was equivalent to 8 and 18 hours grazing as single events respectively. The pattern of use was the same in both years except that fewer plants were grazed in 1990 than in 1989.

Forb and grass use increased with actual hours spent grazing (Equation 2 and 3, $\mathrm{H}=$ actual grazing hours, $\mathrm{P}=$ proportion plants taller than $12 \mathrm{~cm}$ ), however, grass use did not increase linearly with time.

$$
\begin{array}{ll}
\text { forbs }=36.0+1.0 \mathrm{H}+242.6 \mathrm{P} & \text { adj. } \mathrm{R}^{2}=0.40 \\
\text { grass }=28.0+8.5 \mathrm{H}+0.4 \mathrm{H}^{2} & \text { adj. } \mathrm{R}^{2}=0.56
\end{array}
$$

The proportion of forbs grazed was influenced by the proportion of forbs taller than $12 \mathrm{~cm}$, whereas grass use was independent of grass height.

\section{Discussion}

Our picketed horses behaved similarly to free ranging horses (Archer 1973, Mayes and Duncan 1986, Ralston 1984). They grazed during every hour and kept a constant rate of forward motion (number of grazing stations) while grazing. Our animals spent slightly more time grazing than free ranging horses (Mayes and Duncan 1986) and the initial "meal" was slightly longer than the 2 to 3 hour initial feeding bouts reported by Ralston (1984). This is probably because horses do not voluntarily fast more than 3 to 5 hours (Ralston 1984). 

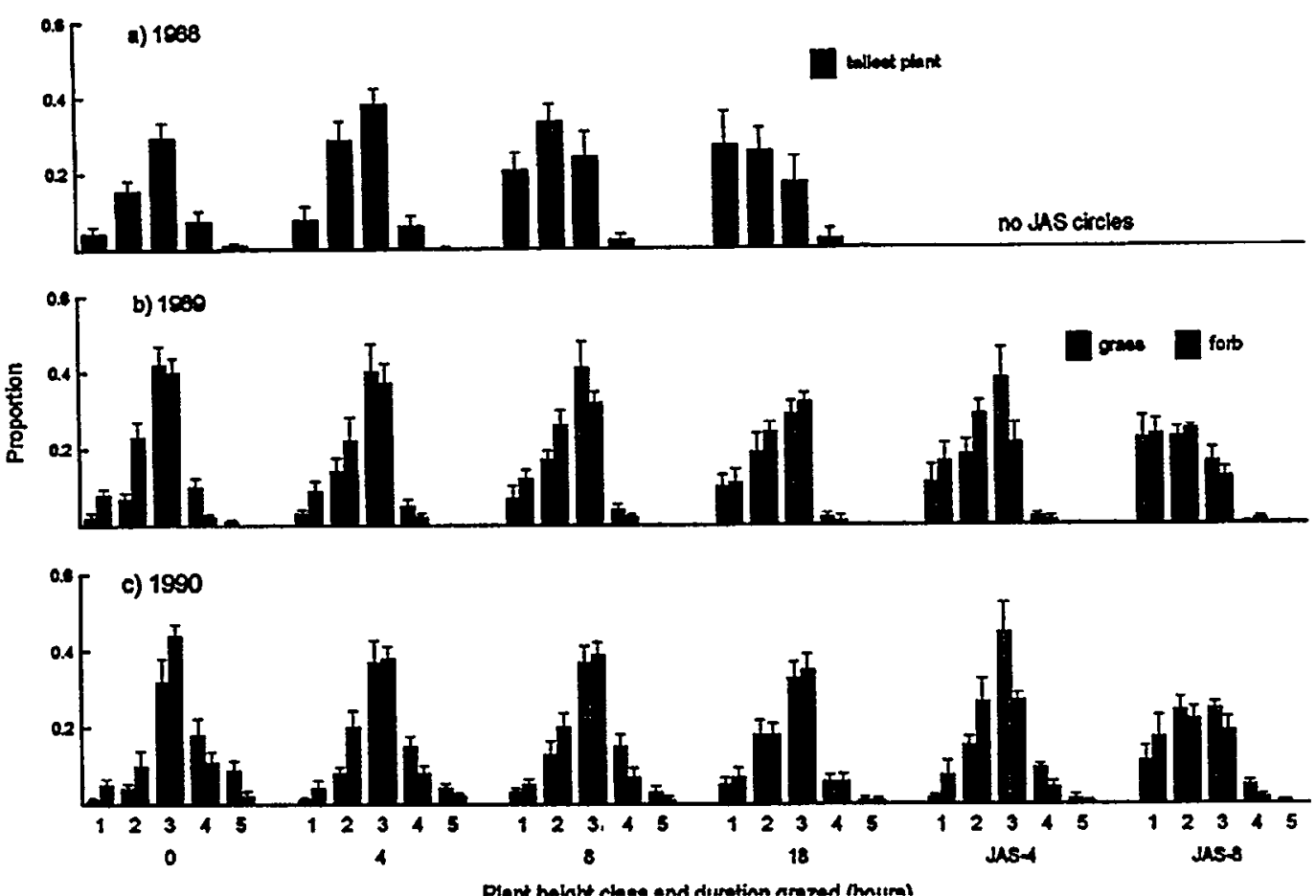

Fig. 2. The proportion of plants in each height class $(1,1-2 \mathrm{~cm} ; 2,2-4 \mathrm{~cm} ; 3,4-12 \mathrm{~cm} ; 4,12-24 \mathrm{~cm} ; 5,>24 \mathrm{~cm})$ after 1 grazing event of $0,4,8$, or 18 hours and repeated grazing of 4 or 8 hours through the summer (JAS-4, JAS-8). The picket circles were grazed in; a) 1988, b) 1989, and c) 1990. Means and standard errors are the average monthly means and standard errors $(N=4$ in each of 3 months). The LSD $=0.08$.

As the horses became accustomed to the area, they spent more time standing and resting rather than walking around on the picket line when not grazing. Exercised horses also tend to be more relaxed and move around less while on picket lines (Duren et al. 1989). Horses that stand quietly when not grazing could be left on picket lines, whereas those horses that are restless may increase damage to meadow communities through trampling.

Our data describe the behavior and impact of horses on $15 \mathrm{~m}$ picket ropes. Handling or picketing methods may influence horses' grazing behavior. Horses picketed on ropes less than $3 \mathrm{~m}$ may not graze because they believe they are tied (Duren et al. 1989). Electric ribbon fence may become popular for containing horses because horses train easily to its use and there is little risk of injury. If properly managed such fencing could distribute a small amount of impact over a large area. However, the temptation would be great to treat the area as a pasture to hold horses whenever they are not in use. Pastured horses can impact up to $90 \%$ of the forage on pasture with trampling, urination, or defecation (Carson and Wood-Gush 1983). Such impacts may not be compatible with other wilderness uses (Moore and McClaran 1991, McClaran and Cole 1993).

The impact of horses grazing an area may also be influenced by plant species composition and structure. Horses are selective grazers when forage quality and availability is high (Mayes and Duncan 1986). Our horses consistently preferred grasses over forbs until forage became limiting, sometime after 8 hours on the picket. Reiner and Umess (1982) reported similar dietary selection by horses grazing an intermountain foothill grass-forb-shrub community. Their horses took more grass than forb bites until the amount of grass biomass removed reached $65 \%$. When grass biomass removed was at $75 \%$, forbs dominated the diet.
We assumed that fewer plants would be grazed in areas where the vegetation was taller. Taller plants would provide more forage per plant and be more susceptible to being bent down by picket ropes, making them undesirable and covering other plants. The data did not support this perhaps because the long durations on the picket circles encouraged horses to graze bent over forage or because more than $80 \%$ of the vegetation was less than $12 \mathrm{~cm}$ tall before grazing. Short vegetation is less susceptible to being bent down and more available for grazing. In areas with taller vegetation, plant damage from picket ropes may be a consideration.

Table 1. Percent of grasses and forbs grazed after picketing horses once for $1,4,8$, or 18 hours, or repeatedly in July, August, and September for 4 or 8 hours each time. Means and standard errors on the $0,4,8$, and 18 hour treatments are the average monthly mean and $S E(N=4$ horses).

\begin{tabular}{lccc}
\hline \hline Year & $\begin{array}{c}\text { Duration } \\
\text { grazed } \\
\text { (Hours) }\end{array}$ & $\begin{array}{c}\text { Grass } \\
(\%)\end{array}$ & $\begin{array}{c}\text { Forbs } \\
(\%)\end{array}$ \\
\hline 1989 & 0 & $23.5 \pm 5.9$ & $8.7 \pm .2$ \\
& 4 & $41.5 \pm 5.8$ & $16.0 \pm 3.9$ \\
& 8 & $52.9 \pm 4.1$ & $23.0 \pm 4.5$ \\
& 18 & $72.4 \pm 6.1$ & $36.5 \pm 8.0$ \\
& JAS-4 & $56.7 \pm 4.1$ & $21.5 \pm 7.1$ \\
1990 & JAS-8 & $77.6 \pm 3.1$ & $35.2 \pm 8.0$ \\
& 0 & $13.3 \pm 5.5$ & $10.7 \pm 3.5$ \\
& 4 & $26.4 \pm 7.2$ & $14.3 \pm 4.3$ \\
& 8 & $41.0 \pm 7.0$ & $20.6 \pm 5.8$ \\
& 18 & $54.9 \pm 7.1$ & $30.7 \pm 7.1$ \\
& JAS-4 & $50.4 \pm 12.3$ & $25.6 \pm 10.4$ \\
& JAS-8 & $69.1 \pm 8.9$ & $29.4 \pm 7.5$ \\
\hline
\end{tabular}


Our data support a positive relationship between grazed plant frequency and hours spent grazing, but we do not recommend graze plant frequency be used as the sole indicator to regulate horse grazing. Circles grazed either once for 18 hours or grazed repeatedly through the summer received heavy use. The immediate impact of such use on a plant community is varied. Since some plant communities evolved with disturbance, for example, by elk grazing or burrowing animals, horse grazing may have an immediate visual impact but not influence the meadow community or may influence the meadow at a rate too slow to measure during a 2 to 3 year study.

\section{Summary}

Picketed horses fed avidly for 3 to 4 hours and continued to graze intermittently thereafter throughout their time on picket circles. They moved continuously while grazing, even when preferred forages were available.

When given a choice, the horses preferred grasses over forbs. Forb use increased with more than 8 hours on the picket as grass became less available. Our horses tended to stand and rest rather than pace when not grazing, thus reducing trampling damage.

With more than 8 hours of grazing or repeated grazing through the summer, most plants were grazed to less than $12 \mathrm{~cm}$ tall. While horse grazing has an immediate influence on wildland meadows its long-term impacts have yet to be identified. Wildland managers must balance the potential immediate and long term impacts of packhorse grazing with the other uses and management objectives of wildland areas when setting packhorse use guidelines.

\section{Literature Cited}

Altmann, J. 1964. Observational study of behavior: Sampling methods. Behav. 49:227-267.

Archer, M. 1973. The species preferences of grazing horses. J. Brit. Grassl. Soc. 28:123-128.

Carson, K. and D.G.M. Wood-Gush. 1983. Equine behaviour: II. A review of the literature on feeding, eliminative and resting behaviour. Appl. Anim. Ethol. 10:179-190.

Cole, D.N. 1987. Effects of 3 seasons of experimental trampling on 5 montane forest communities and a grassland in western Montana, USA. Biological Cons. 40:219-244.

Cole, D.N. 1989. Viewpoint: Needed research on domestic and recreational livestock in wilderness. J. Range Manage. 42:84-86.

Duren, S.E., C.T. Dougherty, S.G. Jackson, and J.P. Baker. 1989. Modification of ingestive behavior due to exercise in yearling horses grazing orchardgrass. Appl. Anim. Behav. Sci. 22:335-345.

Jacobsen, N.K. and A.D. Wiggins. 1982. Temporal and procedural influences on activity estimated by time-sampling. J. Wildl. Manage. 46:313-324.

Mayes, E. and P. Duncan. 1986. Temporal patterns of feeding behaviour in free-ranging horses. Behav. 96:105-129.

McClaran, M.P. and D.N. Cole. 1993. Packstock in Wilderness: Impacts, monitoring, management and research. USDA., For. Serv. Gen. Tech. Rep. INT-301.

Montagne, C., L.C. Munn, G.A. Nielsen, J.W. Rogers, and H.E. Hunger. 1982. Soils of Montana. Montana Ag. Exp. Sta. Bull. 744. 95pp.

Moore, S.D. and M.P. McClaran. 1991. Symbolic dimensions of the packstock debate. Leisure Sci. 13:221-237.
Mueggler, W.F. and W.L. Stewart. 1980. Grassland and shrubland habitat types of western Montana. USDA, For. Serv. Tech. Rep. INT66.

Reiner, R.J. and P.J. Urness. 1982. Effect of grazing horses managed as manipulators of big game winter range. J. Range Manage. 35:567-571.

Ralston, S.L. 1984. Controls of feeding in horses. J. Anim. Sci. 59:1354-1361.

SAS Institute Inc. 1988. SAS/STAT User's Guide, Release 6.03 Edition. Cary, N.C.

Stankey, G.H. and R. Schreyer. 1987. Attitudes towards wilderness and factors affecting visitor behavior. pages 246-293, In: R. Lucas (compiler). Proceedings-National Wilderness Research Conference: Issues, state-of-knowledge, future directions. USDA, For. Serv., Gen. Tech. Rep. INT-220. 